\title{
Osmanlı Devletinin Son Döneminde Anadolu'ya Gelen Muhacirler ve Muhacirlerin Göç Ettiği Bazı Şehirlerdeki İskân Politikaları
}

\author{
DOI: $10.26466 /$ opus. 576880
}

\author{
* \\ $\underline{\text { Ahmet Oğuz* }}$ \\ *Doç. Dr. Nevşehir Hacı Bektaş Veli Üniversitesi, Nevşehir / Türkiye \\ E-Posta: ahmetoguz@nevsehir.edu.tr \\ ORCID: 0000-0000-1991-1102
}

Öz

Osmanlı topraklarına gö̧ç Kırım'ın kaybıyla başlamış ve artı̧̧ göstermiştir. Osmanlı ordularımın yenilmesiyle beraber bu bölgelerden Anadolu'ya göçler hızlanmıştır. Müslüman Türk nüfusun yoğun olduğu bölgelerin kaybı Anadolu'ya göçü artırmıştır. En kesif göç dalgası 93 Harbi ve Balkan Harbi'yle olmuştur. Rusya'nın Balkanlarda ve Kafkaslarda bulunan Osmanl topraklarnda Türk ve Müslüman nüfusun yoğun olduğu yerleri işgal etmesi kitleler halinde göçün Anadolu'ya akmasina sebebidir. Osmanlı Devleti'nin ikinci büyük göç dalgası Balkan Savaşı'nın kaybedilmesiyle başlamış ve sonrasında da devam etmiştir. Balkanlardan ve Karadeniz'den gelen muhacirlerin toplanma merkezi İstanbul olmuştur. Savaşların kaybıyla başlayan göç dalgası İstanbul hükümetlerini bir hayli sarsmıştır. Örneğin İstanbul'a gelen muhacirleri toplayacak adeta yer kalmamış, padişah dahi sarayını açarak misafir kabul etmiştir. İstanbul sokaklarına sığmayan muhacirleri ülkenin değ̆işik yerlerine göndermek için yoğun çaba harcanmıştır. Önce İstanbul'da toplanan mülteciler daha sonra uygun şehirlere gönderilmişlerdir. Gelen göçmenler arasında bulunan 'Çerkes Muhacirler'in çapul ve yağma yaptıkları gibi iddialar ortaya atılmıştır. Meclis-i Mebusan'ın açık olduğu dönemde Çerkes göçmenler, Müslim gayrimüslim mebuslar arasında tartışmalara sebep olmuşlardı. En önemli göç olaylarından biri de 'zor yıllar'diye bileceğimiz 1911-1912 Balkan Savaşları sonrasında yaşanmıştır. Bu dönemi zorlaştıran bir başka etken ise devletin imkânlarınn gittikçe tükenmesiydi. İ̧̧ isyanlar ve dış saldırlların devletin insan ve mali kaynaklarını iyice eritmişti. Uzun yıllardır göç alan Anadolu şehirleri artık muhacir kabul etmek istemediklerini merkezi hükümete bildirmiştir. Balkanlar ve Kafkaslardan gelen mülteciler Anadolu'ya iskân ettirilmişlerdir. Osmanl Devleti son yüz yılında Anadolu'ya akan mültecilerle başa çımak zorunda kalmıştır. Gelen bu mültecilere barınma ve beslenme hususunda devletin imkânları kullanıldığı gibi Anadolu halkı da bu insanlara kucak açmıştır.

Anahtar Kelimeler: Osmanlı Devleti, Balkan Savaşları, Anadolu, muhacir 


\title{
Immigrances of Anatolia in The Last Term of The Ottoman State and Public Policies in Countries of Immigrants
}

\begin{abstract}
The migration to the Ottoman lands started with the loss of Crimea and increased. With the defeat of Ottoman armies, migrations accelerated from these regions to Anatolia. The loss of the regions where the Muslim-Turkish population was concentrated increased the migration to Anatolia. The most intensive migration wave was caused by 93 War and Balkan War. Russia's occupation of the Ottoman's Balkans and Caucasus territories where the Muslim-Turkish population was concentrated had caused mass migration to Anatolia. The second great wave of migration of the Ottoman Empire began with the loss of the Balkan War and continued afterwards. Istanbul had been the center of gathering of refugees from the Balkans and the Black Sea. The wave of immigration that started with the loss of wars greatly shook the governments of Istanbul. For example, the emigrants who came to Istanbul had no place to shelter, even the sultan opened his palace and accepted guests. Intensive efforts had been made to send refugees who do not fit in the streets of Istanbul to different parts of the country. The refugees were first gathered in Istanbul and then sent to the appropriate cities. It was claimed that the Circassians which is accepted among immigrants committed plundered the city. At the time the parliament (Meclis-i Mebusan) was open, Circassian immigrants issue had caused controversy between Muslim and non-Muslim deputies. One of the most important migration events took place in the aftermath of the Balkan Wars of 1911-1912, Which we know as difficult years. Another factor that made this period difficult was that the opportunities of the state gradually decreased. Internal rebellions and external attacks had devastated the human and financial resources of the state. Anatolian cities, which had been migrating for many years, had reported to the central government that they no longer want to accept immigrants. Refugees from the Balkans and the Caucasus were settled in Anatolia. In the last century, the Ottoman Empire had to deal with the refugees flowing to Anatolia. As the state's facilities were being used for sheltering and feeding these refugees, the Anatolian people had embraced these people.
\end{abstract}

Keywords: Ottoman Empire, Balkan wars, Anatolia, immigrant. 


\section{Giriş}

İnsan göç dini, iktisadi, siyasi, sosyal ve diğer sebeplerden dolayı insan topluluklarının bir yerden başka bir yere gitmesidir. Ayrıca göç kişisel nedenlerden dolayı yer değiştirme de bu tanımlamanın içine almaktadır. Hatta göç diğer canlıların da örneğin hayvanların da bir yerden bir yere gitmesini içerir(Saraç, 2011, s. 1052). Türkler de Orta Asya'dan başlayarak dünyanın pek çok bölgelerine tarihleri boyunca göç etmişlerdir. Her göç olayında olduğu gibi daha iyi bir yaşam kurmak başta olmak üzere çeşitli sebeplerle göçler yapılmıştır. Balkanlara doğru yayılan Türk nüfus Balkanlara giderken fatihlerin arkasından gitmiş, vardıkları yerlerde de yerli halkla kaynaşarak bölgeyi imar ve irşat etmişlerdi. Osmanlı ordularının gelmesiyle beraber bölge halkı göç etmemiştir. Aksine fetihlerle gelen göç halka refah getirmiş ülkelerin nüfuslarını artırmıştır. Balkanlarda Hıristiyan halkın yaşadığı yerler kaybedilmiş olmasına karşın oralardan bölgeyi etkileyecek şekilde herhangi bir Hristiyan göçü olmamıştır. Osmanlı Devleti oraları fethettiği zaman bölgenin halkına geniş bir hoşgörü sunulmuştur. Devletin alması gereken vergileri alarak yerel otoritenin feodal yaşamın sürdürülmesine imkân tanımıştır (Çetin-Çağ, 2013, s.287).

Ancak Türklerin Balkanlardan dönüşleri bu şekilde olmamıştır. 19. Yüzyıldan itibaren Türk ve Müslümanların Balkanlardan Anadolu'ya göçleri ise savaştan kaçmak ve hayatta kalmak için yapılan zorunlu göçlerdir. Türklerin fetih dönemlerinde Balkanlara Anadolu'dan giden göç Osmanlı Devleti'nin geri çekilmesiyle Anadolu'ya doğru olmuştur. Anadolu'ya zorunlu göçler Müslüman nüfusun yaşadığı, yoğun olduğu Kırım'ın 1783 yılında kaybıyla başlamıştır (Uzunçarşılı 2007: 491). Kırım'dan sonra daha başka yerler de kaybedilmiş böylece göçler de sürekli hale gelmiştir. Yakın bölgeler haricinde de Anadolu'ya göçler olmuştur. Rus zulmünden kaçıldığı gibi Çin zulmünden de Doğu Türkistan'dan ve diğer Türk coğrafyasından Anadolu'ya acı hikâyelerle göçler olmuştur (Gayretullah, 2006, s.136).

Çar Deli Petro ile başlayan Rusya'nın Akdeniz'e inme çabaları Osmanlı Devleti'nin kuzey siyasetini de belirlemiş̧tir. Ruslar aşağıya doğru inip Rus baskısı Osmanlı üzerine geldikçe göçler artmıştır. Osmanlı Devleti'nin Rusya'ya karşı 93 Harbi'ni kaybetmesiyle dağılmaya başladığı 
son dönemlerde ise hem Balkanlardan hem de Kafkaslardan gelen muhacir sayısı da aynı oranda artmıştır. Osmanlı Devleti'nin yenilgiyle çekildiği bölgelerden göçler de o nispette hızlı olmuştur. Özellikle Balkanlar'dan Anadolu'ya yapılan göçler insan sayısı ve çekilen sefalet olarak büyük boyutlardadır. 93 Harbi'nden sonra kış günü üstü açık vagonlarla geldikleri gibi nüfusun çocuğunu yollarda kaybedilmiştir(Oğuz, 2010, s. 216). Kafkaslardan yapılan göçlerin de bundan pek farkı yoktur.

Türklerle meskûn olan Balkanlar başta olmak üzere diğer bölgelerdeki toprakların kaybıyla da her bölgeden Anadolu'ya doğru değişik yollarla muhacir gelmiştir. Gelenler kadar bir de gelemeyenler tarafı vardır. Özellikle Bulgaristan'ın hem Anadolu'ya açılan kapı olması hem de Türk ve Müslüman nüfus bakımından yoğun bir nüfusu barındırması buradaki dramı artırmıştır. Bulgarlar da bölgeyi Bulgarlaştırma çabasına girmiştir. Bölgeye önemli Rus ajanları gönderilerek Bulgarların göçü teşvik edilmiştir (Karpat, 2013, s. 161) . Bulgarların çete faaliyetlerinde bulunmaları ve Rus desteğini arkasına almaları buna karşın Osmanlı kuvvetlerinin güçsüzlüğü vahşetin boyutlarını artırmıştır. Bulgar çetelerinin Avrupa devletlerinin dikkatini çekmek amacıyla yaptıkları Türk soykırıma dönüşmüştür. Bulgar çeteleri planlı bir katliama başlamışlardır. Savaşın başından beri bölgede hâkim olan Bulgar çetelerinin Rus kuvvetlerinin desteğiyle çıkardığı isyan Osmanlı başıbozuk kuvvetlerle takviye etmesiyle bastırılabilmiştir. İsyanın bastırılmasında başıbozuk Osmanlı güçlerinin orantısız güç kullanmış olması hatta kimi Osmanlı memurlarının mahkeme yapmadan cezalar vermeleri Osmanlı Devletini zor duruma düşürmüştür(Yetişğin, 2013, s. 753). Osmanlı Devleti'nin hem düzenli kuvvetlerinin olmaması hem de asayişi sağlayacak bir başka çare bulamamaları sebebiyle Kafkaslardan gelen Çerkezler başta olmak üzere eli silah tutan kimseler silahlandırılmıştı. Fakat başıbozuk olarak adlandırılan bu güçler asayişi temin edemedikleri gibi yağma ve talan işlerine de girerek Osmanlı Devleti'nin itibarına zarar vermiş, bu kuvvetler masum halka da zulümler yapmıştır. Bu durum Bulgarların da propagandasıyla Avrupa kamuoyunu ayağa kaldırmak için geçerli bir sebep ortaya çıkarmıştır (McCarthy, 1995, s. 61). Bulgarların 'Türkler katliam yapıyor.' şeklinde yaptıkları propaganda onları haklı gösterdiği gibi Osmanlı Devleti'nin de Batı kamuoyunda yalnız kalmasına sebep olmuştur. Rusya da Batıdan soyutlanan Osmanlı Devleti'ne istediklerini daha kolay 
yaptırabilmiştir.Avrupa devletlerinin dikkatini bölgeye çekmek amacıyla hedeflerine kanlı olarak ulaşmak isteyen Bulgarlar, Türk ve Müslümanları engel olarak gördüklerinden durum soy kırıma dönüşmüştür. Avrupalı gözlemcilerin raporlarında katliamlar açıkça yazılmışsa da Batılı devletler herhangi bir önlem alınmamıştır (Karpat, 2004, s.221).

Türk milleti asırlardır vatan olarak bildiği Balkanlardan yalnız göç ettirilmekle kalmamış, bu süreçte büyük bir soykırıma da uğramıştır. Fransız ihtilalinin bir sonucu olarak ortaya çıkan mikro milliyetçiliğin de etkisiyle Balkanlı gayrimüslim Osmanlı vatandaşları yıllardır birlikte yaşadıkları komşuları Müslüman halka saldırmışlardır. Onları göçe ya da ölüme mahkûm ederek yeni bir devlet kurma yoluna gitmişlerdir. Bu sebeple Sırpların, Herseklerin, Karadağlıların ve nihayet Bulgarların zulmünden kaçabilenler kaçmış, kaçamayanlar ise soykırıma uğramıştır. Bugün Balkan coğrafyasında bulunan devletlerde Türk nüfusun yok denecek kadar az oluşu bunu doğrulamaktadır. Diğer yandan Osmanlı Devleti'nin uzun asırlardır bıraktığı Türk mimarisi de Türk nüfus gibi zarar görmüştür. Balkanlar'a asırlardır hâkim olan Osmanlı Devleti'nin mimari izleri neredeyse yok denecek hale gelmiştir. Anlaşılmaktadır ki Balkanlar başta olmak üzere Osmanlı Devleti'nin hükümranlığının sona erdiği her bölgede Müslüman Türk nüfus ile beraber Osmanlı mimarisi de yok olmuştur.

Türklerin uzun süre yaşadığı Balkanlardan ve Kafkaslardan olmak üzere Anadolu'ya yoğun bir Türk ve Müslüman muhacir akını olmuştur. Çok milletli ve çok kültürlü bir yapısı olan Balkanlardan Osmanlı hâkimiyeti çekilince bölge karışmıştır. Bu karışıklıkta Müslümanlar ve Türkler değişik milletlere bağlı Hristiyan milletler tarafından geçmişin suçlusu ve sorumlusu olarak görülmüştür. Bu sebeple yaşadıkları topraklardan göçe zorlanmışlar hatta katliama uğramışlardır. Doğudan gelenler için de durum farklı değildir. Kırım'ın kaybı başta olmak üzere Rus orduları güneye doğru ilerledikçe yerinden yurdundan olan, ölüm tehlikesi yaşayan daha ötesi katledilen Müslümanlar ve Türkler Anadolu'ya sığınmışlardır. Bu insanlar hem Rus ordularından hem de Ermenilerden kaçmışlardır. Anadolu'ya gelişin üçüncü bir yolu olarak da deniz kullanılmıştır. Hem Balkanlardaki limanlardan hem de Karadeniz limanlarından muhacirler Anadolu'ya gelmiştir. 


\section{Balkanlardan Gelen Göçler}

Balkanlar, Osmanlı fetihlerinin ağırlık noktasıydı. Bu yüzden Bulgaristan, Romanya, Yugoslavya ve Yunanistan Anadolu'ya ekseriyetle göç veren ülkelerdendir. Rusların baskıları arttıkça ve de bağımsızlıklarını kazanarak sınırları genişledikçe göçler de artmıştır. Romanya' dan 1812 yılında 200.000 tahmin edilen insan sayısı daha sonraları gittikçe artmıştır. Bu göçler Anadolu'nun her tarafına yayılmıştır. Bulgaristan'dan da 1828 yılından itibaren başlayan göçler, Bulgar zulmüyle de beraber oldukça şiddetli olmuştur. Yugoslavya'dan da Romanya'dan olduğu gibi 1812 yılından itibaren Sırp ayaklanmalarının durumuna göre göçler başlamıştır. Yunanistan'dan ise Mora yarımadasında isyanın başlamasıyla göçler hatta toplu katliamlar başlamıştır. Avrupa devletleri ve Yunan hayranları eski çağların medeni halkını barbar Türklerden korumak için gönüllü olarak Mora yarımadasına akarlarken Trapliçe'de otuz iki bin Türk medeniyet göstergesi olarak toplu halde katledilmiştir(Kaflı, 1966, s. 24).

Osmanlı Devleti 93 Harbi'yle Balkanlarda askeri üstünlügünü kaybedip topraklar elden çıkınca Anadolu'ya doğru yoğun bir göç dalgası başlamıştır.Bu dalga kaybedilen topraklardan iki yönlü olarak artmıştır. Balkanlar ve Kafkaslar bu girişin iki ana kapısını meydana getirmiştir. Rus ordularının ilerleyişi karşısında apar topar yollara düşülmesi, ulaşım vasıtalarının sınırlı, göçmenlerin de çok olması faciayı artırmıştır. Artık yollardaki kayıplar, çetelerin insafına terk edilen silahsız ve savunmasız masum halkın katliamı yalnız belgelere girmekle kalıyordu. Avrupalı devletlerin konsolosları bu soy kırımı yazıya aktarmakla yetiniyorlardı(McCarthy 1995: 89). Yollara düşen Türkler, Rus ordularından kaçtıkları gibi Bulgar çetelerin göç güzergâhlarına kurdukları tuzaklarda da büyük kıyımlara uğramışlardır. Bu tuzaklardan kurtulan Türkler hem göç yollarında hem de İstanbul ve diğer şehirlerde salgın hastalık, açlık ve benzeri sebeplerle kırılmıştır. Öte yandan geldikleri yerlerde de bir barınak buluncaya kadar büyük kayıplar vermişlerdir. Osmanlı DevletininBulgaristan toprakları soy kırımın yaşandığı yerlerden biri olmuştur. Hızla güneye ilerleyen Rus askerleri, Bulgar topraklarındaki Müslüman halkı bilinçli bir şekilde yerlerinden ayrılmaya zorladıkları için katliam dâhil her türlü baskıyı yapmışlardır. Ruslar, savaş taktiği olarak 
da Osmanlı ordusunun manevra alanını daraltmak amacıylaTürk göçünü teşvik etmişlerdir.

Bulgar bağımsızlık hareketi, Bulgar kilisesinin bağımsızlığını almasıyla önceden beri planlanan müstakil Bulgar Devleti kurulması sürecine daha da yaklaşmıştır. Rus orduları ilk kez 1828-29 Osmanlı Rus savaşında Balkan dağlarını aşarak Edirne'ye gelmişlerdi. O zaman henüz teşkilatlanmamış olan Bulgarlar Türkler için bir tehlike oluşturmamıştı. Ancak 1877-78 Osmanlı Rus savaşında ise milli kimlik oluşturmuşlar, silahlanmışlar ve askeri olarak Rusları desteklemişlerdir. Türklere karşı yürüttükleri çete faaliyetleriyle Bulgaristan'da katliam yapmışlardı. Ruslar, Rusçuk ve özellikle Plevne'de Osmanlı ordusunun yerel olarak gösterdikleri mukavemeti kırmışlar Sofya, Filibe ve Orhaniye yoluyla Edirne'ye varmışlardı (Uzunçarşılı, 1988, s.52). Rus düzenli birlikleri Müslüman yerleşim yerlerine ve göç kafilelerine saldırmışlardı. Bu saldırılardan korkan halk yükte hafif pahada ağır ne eşyaları varsa alıp göç yollarına düşmüşlerdi. Yollara düşen halk, trenleri de doldurduğu için yüz binlerle ifade edilen göç dalgası Osmanlı ordusunun geçiş noktalarını da tıkamaktaydı.

Bölgede bir başka unsur daha vardı: Çerkesler. Onlar, 93 Harbi sonrası Rumeli'den gelen guruplar içinde bazı problemlere sebep olmuşlardır. Kafkaslarda İmam Şamil'in 1859 yılında esir düşmesiyle Kafkaslardan önce Balkanlar'a göç etmek zorunda kalmışlar, daha sonra Balkanlar'ın da Rusların istilasına uğramasıyla tekrar Anadolu yollarına düşmüşlerdi. Elinde mevcut silahlı askeri bulunmayan Osmanlı Devleti, silahlandırabildiği Çerkesleribaşıbozuk kuvvet olarak kullanmıştır. Osmanlı hükümetince silahlandırılan Çerkes kuvvetler Bulgarların Müslüman halka karşı yaptığı katliamlara karşılık vermişler ancak bunun yanında yağma ve çapul hareketlerinde de bulunmuşlardır.Bu durumu rapor eden bölgedeki Avrupa elçilerininraporlarında 'Türkler katliam yapıyor.' propagandasıkonunun Avrupa kamuoyuna yanlı bir şekilde yansitılmasına sebep olmuştur (McCarthy, 1995, s. 57).

ÇerkeslerinBalkanlardan Anadolu'ya gelirken düzensiz kuvvet halinde de olsa Bulgar ve diğer çetelere karşı kendilerini savunacak durumdaydılar. Dolayısıyla saldırılara cevap verecek kabiliyetleri vardı. Bu durum henüz açık olan Osmanlı Meclis -i Mebusanı'nda da tartışılmıştır. Gayri Müslim mebuslar Çerkeslerin yağma, çapul ve katliam yaptıklarını 
iddia etmişlerdir. Müslüman mebuslar ise 'izzet-i nefs' ile hareket ettiklerini savunmuşlardır. 1877-78 Osmanlı meclisinde Müslümanlarla gayri Müslim mebuslar arasında yaşanan en şiddetli tartışmalardan biri olmuştur. ${ }^{1}$ Çerkeslerle ilgili Balkanlardaki benzer durum Kafkaslarda da olmuştur. Savaşta cesaret ve kahramanlıkları takdir edilse de uygunsuz hareketlerinin orduya ve devlete zarar verdiği de kimi Osmanlı gözlemcileri tarafından da eleştirilmiştir.

Osmanlı Devleti'nin yenilmesiyle Balkanlardan başlayan tersine göç benzer şekilde Kafkaslardan da olmuştur. Aynı sebeplerle Rus baskısında kaçan Müslüman topluluklar başta Türkler olmak üzere yaşama şanslarını Anadolu'ya göç etmekte bulmuştur. Rusların Kafkaslarda kolay ilerleyişi bu göçleri hızlandırmıştır. Savaş sonrasında Müslümanların mülklerinin değişik sebeplerle ellerinden alınarak kuzeyden gelen Rus göçmenlere verilmesi savaşlar sonrasında da göçlerin mütemadiyen devam etmesine sebep olmuştur. Rusların kışkırtması sonucu Ermenilerin debölgedeki Müslüman halka karşı kuvvet kullanarak yıldırma, göç ettirme ve katliama varan şiddet eylemleri göstermeleri sebebiyle Kafkaslardan iç bölgelere doğru göçler olmuştur. Ruslarla yapılan savaşların kaybedilmesi üzerine Kırım başta olmak üzere bölgeden çok sayıda göçler olmuştur.Bu halklar içinde Çerkezler dâhil olmak üzere Rus ordularından kaçan bölgenin Müslüman halkı Osmanlı topraklarına,Anadolu'ya sığınmıştır.

\section{Kafkaslar'dan Anadolu'ya Muhacir Göçü}

Anadolu'nun göç yollarından biride Kafkaslardır. Kafkas Dağları'yla Doğu Anadolu'yu içine alan Kafkaslar bölgesi Müslüman ve Rus istilasının Balkanlardan sonra hissedildiği önemli bir bölgedir. Müslüman ve Türk nüfusun yoğun ve hareketli olması yanında Ermeniler de bölgede dağınık olarak bulunmaktadır. Ermenilerden başka Gürcüler, Keldaniler, Nasturiler ve Rumlar bölgenin başlıca sakinleriydi. Müslüman ve Türkler üzerinde Rus baskısı arttıkça, Ruslardan destek alan Ermeniler de Müslüman ve Türkler üzerine baskıyı artırmışlardır. Osmanlı -Rus

\footnotetext{
1 1877-1878 yıllarında faaliyet gösteren Osmanlı meclisinde bu konuda yapılan tartışmalar için (Oğuz 2010, s.218-219).
} 
savaşlarının yapıldığı yıllarda Rus saldırıları Balkanlarla beraber Kafkasya'dan da gerçekleştiği için Anadolu, Kars ve Erzurum yoluyla yoğun göçler almıştır. Bu göçler İkinci Dünya savaşının sonuna kadar yoğunluğu değişmekle beraber devam etmiştir. Göçler Anadolu'nun her tarafına olmakla beraber Kırım Tatarları Eskişehir bölgesine daha çok yerleşmişlerdir. Bu arada Azerbaycan'dan da Kars, Iğdır ve Erzurum civarına göçler olmuştur. Azerbaycan'dan göçlerde Ermenilerin Ruslarla birleşerek Azerbaycan Türklerini yurtlarından kovmak ve devlet kurma arzuları da bu göçleri kamçılamıştır(Kaflı,1966, s.19 vd.). Aynı sebepler Doğu Anadolu için de geçerlidir.

Bölgede bulunan Ermeniler Rus teşvikiylegöçün yönünü kimi zaman da tersine çevirmiştir. Örneğin 1828-1829 Osmanlı Rus savaşında Erzurum'a kadar ilerleyen Ruslarla beraber çok sayıda Ermeni Rusya'ya gitmişti. Diğer yandan İstanbul patrikliğine bağlı olmak istemeyen kimi piskoposlar Eçmiadzin patrikliğine bağlanmışlardı. Bu durum Doğu Anadolu'dan göçen bir Ermeni nüfusun Erivan bölgesinde yoğunluk meydana getirmesine sebep olmuştur.

\section{Anadolu Şehirlerine Yapılan Göçler}

Osmanlı Devleti artan muhacir akınını bir düzene bağlamak amacıyla 5 Ocak 1860 tarihinde Göç Komisyonu kurmuş ve her taraftan gelen göçmenleri İstanbul'da toplamak istemiştir. 93 Harbi sebebiyle devletin imkânları yeterli olmayınca 23 Ocak 1878'de Hilal-i Ahmer Cemiyeti ve 24 Ocak'ta ise Milletler Arası Muhacirlere Yardım Komitesi Avrupa'daki hayır kurumlarına yardım çağrısında bulunmuşlardır. Bu yardım çağrısı karşılıksız kalmamış değişik ülkelerden yarımlar gelmiştir (İpek, 1999, s. 79). Bunun için İstanbul'da değişik semtlerde şubeler oluşturulmuştur. Anılan komisyon bir süre Zaptiye Nazırlığı'na bağlandıysa da işlerinin ağırlaşması sebebiyle müstakil hale getirilmiştir (Paşaoğlu, 2013, s. 352). Fakat bir süre sonra İstanbul üzerinden dağıtmak zor olduğundan Anadolu'nun değişik yerlerine uygun vasitalarla muhacir gönderilmiştir. Eğer arazi ve barınma şartları uygunsa isteyenleri istedikleri yerlere, akrabalarının yanlarına sevk edilmişlerdir. Böylece işlerin hızlandırılması ve göçmenlerin salgın hastalıklardan ve açlıktan telef olmalarının önüne geçilmek istenmiştir. Göç idaresinin kararıyla yapılan bu sevkler isteğe 
bağlı olduğu gibi zaruretler neticesi de gerçekleştiği de olmuştur. Devletin elinden geleni yaptığı gibi vardıkları mahallerde de bölge halkı muhacirlerehayatta kalabilmelerini sağlayacak gerekli desteği vermiştir.

$O$ günün şartlarında her türlü ulaşım vasıtalarını kullanmışlardır. Gemilerle gelen Balkan göçmenleri, Balkanlardaki Osmanlı şehirlerinden Anadolu'ya deniz yoluyla gelişlerinde göçmenlerin Karesi Vilayeti üzerinden Konya Vilayeti'ne gelecekleri güzergâh Gelibolu'ya uğradıktan sonra Lapseki'ye uğramadan gitmeleri için talimat verilmiştir. ${ }^{21878}$ yoğun göçü bu güzergâh kullanılarak yapılmıştır.

93 Harbi sonrasında göçlerin bir miktar azaldığı, hız kestiği görülmektedir. Balkanlardan yine deniz yoluyla göçmen sevkiyatı yapılmıştır. Ancak göçe tabi olan nüfusun sayısında bir düşüş görülmektedir. Bulgaristan'da Müslüman ve Türklerin göç ettirilesi devam etmiştir. Göçmenlerin Varna iskelesi yoluyla Hüdavendigar vilayetine atmış sekiz göçmenin gönderildiği belgelerde yer almaktadır. ${ }^{3}$ Bu belgeye konu olan nüfus miktarının azlığı göç dalgasının 93 Harbi sonrasında yavaşladığının bir işareti olsa gerektir.

İstanbul'da göçmen yoğunluğu olması sebebiyle Kafkaslardan gemilerle gelenler İstanbul'a gönderilmek yerine gidecekleri en yakın limanlara götürülerek, iç bölgelere sevk edilmişlerdir. Örneğin Batum ve Artvin'den gelen göçmenler Karadeniz sahil şeridine yerleştirildikleri gibi doğrudan İstanbul'a gönderilerek oradan da Adapazarı, Sakarya, Bolu, Eskişehir ve Ankara'dan Adana'ya kadar olan bölgeye yerleştirilmişlerdir. Karadeniz'den gelen göçmenlere Balkanlar'dan gelen göçmenler de eklenince 1887 yılından itibaren gemilerin İstanbul'a değil göçmenlerin yerleşe bileceği yakın yerlerdeki uygun limanlara sevk edilmesi kararlaştırılmıştır(Demirel, 2009, s. 323).

\section{Muhacirlerin Anadolu'ya Yerleştirilmesi ve İskân Politikası}

Savaşlar ve ölüm korkusuyla Kafkaslar ve Balkanlardangöç eden muhacirler Anadolu'nun uygun yerlerine yerleştirilmişlerdir. Bu göçler sadece savaş zamanlarında değil Rusların güneye yayılma ve Rus halkına

${ }^{2}$ DH. MKT., 1346/25, H. 16. 2. 1302 / 5 Aralık 1884.

${ }^{3}$ Y..PRK.., KOM., 4-71, H. 27.11. 1302/ 7 Eylül 1885. 
yer açma politikasının da bir parçası olarak da göçler yaşanmıştır. Biz bu çalışmada Anadolu'da yoğun göç alan bazı şehirlere gelen muhacirlerin iskân şartları ve yapılanların genel bir değerlendirmesi üzerinde durulacaktır. Muhacirlerin gönderildiği bazı yerleşme meseleleri ele alınacaktır. Bu süreçte en çok göç alan yerlerden birisi de Akdeniz sahil şeridi ve Antalya'dır.

Diğer Anadolu şehirleri gibi Antalya halkı da şehirlerine gelen muhacirlere elinden gelen desteği esirgememiştir. Ev yapımı bunlardan birisidir. Antalya'da yetmiş hanelik bir tamir edilerek Balkanlardan gelen muhacirlere verilmiş, anılan yerin adı göçmenlerin isteği üzerine Kırımlı olarak belirlenmiştir. İsmin resmileşmesi için de Konya'da bulunan $\mathrm{Mu}-$ hacerat Komisyonu'na bilgi verilmiştir. Yerleşmenin ihtiyaçlarının karşılanması için muhtar seçimi yapılmış ve imam tayin edilmiş, mühür kazdırılmıştır. ${ }^{4}$ Yeni isimler verilmesi konusunda dönemin siyasi yapısına uygun davranılmıştır. Örneğin Girit'ten gelen muhacirlerin oturdukları yerlere Osmaniye, yeni yapılan camiye Reşadiye adı verilmiş ve onlar için yapılan okula da Meşrutiyet adı verilmiştir. ${ }^{5}$ Yalnız yerleşim yeri yapılmamış okul cami gibi sosyal ihtiyaçların da karşılanması amaçlanmıştır. $\mathrm{Bu}$ isimlendirmeler son dönem yerleşmelerinin zamanını göstermesi bakımından da dikkate değerdir.

Anadolu'ya muhacir akınınınyoğun olduğu dönemlerde eğitim ve öğretimin de zaman zaman aksadığı görülmektedir. Antalya'ya gelen göçmenlerin bir yere yerleştirilememesi üzerine medreselere yerleştirilmişlerdi. Ancak bu durum medresede ders görenlerin şikâyeti üzerine eğitim ve öğretimin aksamasına sebep olan durumu İstanbul'a bildirmiştir. Müftüyle beraber on kişi vilayete çektikleri telgrafta medreselerin mültecilere ayrılması dolayısıyla derslerin aksadığını duruma çare bulunması istenmiştir. Antalya'dan alınan şikâyet Konya vilayetine bir emirle bildirilerek medreselerin öğretime geçebilmesi için boşaltılması ve muhacirlerin başka yere yerleştirilmeleri talimatı Konya valiliğinden Antalya'ya iletilmiştir. Bunun üzerine muhacirler de barakalara yerleştirilerek medresede eğitimin yapılması sağlanmıştır. ${ }^{6}$

\footnotetext{
${ }^{4}$ DH. MKT., 1393-72, H. 24.4.1304 /20 Ocak 1877.

${ }^{5}$ DH.. i. D.. 85-1, H. 13. 9. 1328/ 18 Eylül 1910.

${ }^{6}$ BEO., 107-8004, H. 26.04. 1310/ 17 Kasım 1892.
} 
Gelen muhacirlerin medreselere yerleştirilecek derecede yoğun şekilde gelmelerine karşın hem barınma ve beslenme ve hem de onların eğitimleriyle de ilgilenilmiştir. Muhacirlerin istekleri üzerine yaşları uygun olanların Darü'ş-şafaka'ya kaydedilmesi yönünde talep gelmiştir. Darü'şşafaka'nın şartlarına uyanların kabul edildiği anlaşılmaktadır. Adı geçen kurum kabul şartlarını bozmadan muhacirlerden de öğrenci alabileceğini bildirmiştir. Buna göre on iki yaşındaki çocuk birinci sınıfın sorularına cevap verebilecekse kabul edilebilecektir. İkinci sınıfa gidebilecek olanların on üç yaşından fazla olmaması ve fakir olduklarının ispatı ve ana babasının olmamasi ya da ya anasindan ya da babasindan yetim olmasi bunların yanında "ilel ü emrazdan ari ve suiteşahhusa(şahıs hatırlama, tanıma) ve belahetten(aptal, budala) masum bulunmaması, sui ahlakla me'lüf olmaması ..." şeklinde şartlar öne sürülmüştür. Ayrıca okula kabul edilecek çocuklarda öğrenme kabiliyetinin olmaması gerekmekte-yani okuma yazmayı okulda öğrenmesi istenmekte- ve okula alınacak durumda olduklarının okul tarafından oluşturulan komisyon karşısında kendilerini ispat etmeleri istenmiştir. Bunların dışında okul "cemiyet-i İslâmiye'nin maksadına uygun..." öğrenci seçiminin yapılacağı ilave edilmiştir. Okul için de gerekli iaşenin de yapılması şartıyla öğrenci kabulünün yapılacağı Konya, Kastamonu, Aydın, Halep, Hüdavendiğar ve Trabzon valiliklerine bildirilmiştir. İki varak olan belgenin ikincisinde de aynı şartlar tekrar edilerek Adana, İşkodra, Trablusgarb, Kosova, Manastır, Selanik ve Yanya'ya da haber gönderilmiştir. ${ }^{7}$

Osmanlı Devleti 93 Harbi'nin baskısını üzerinden atıp, muhacirlerin gelişi de zaman içinde yavaşlayınca kimi şehirlerde devletin yaptığ yardımlar belirli oranda artmıştır. Örneğin Konya'da mültecilere yapılan yardımın artırılması kararlaştırılmıştır. Fakat önceden ne kadar verildiği bilinmemektedir. Buna göre Konya vilayetine Meclis-i Vükela'dangönderilen bir tezkerede muhacirlere verilen yardım miktarının artırılması istenmiştir. Tezkerede mültecilerin ekonomik durumlarının tespit edilemeyeceği göz önünde bulundurularak kendilerine verilen yiyeceğin yetişkin ve çocuk sayılarına bakılarak artırılması istenmiştir. Belgede küçük olarak on yaş kabul edilmiştir. Bu sinıflamaya göre "on yaşından küçüklere yarım kıyye ve on yaşından büyüklerine de üçer yüz dirhem nantayinât

${ }^{7}$ DH. iD...60-15, H. 22.9.1330/4 Eylül 1912. 


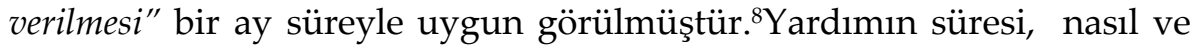
neye göre belirlendiği konusunda belgede bilgi verilmemiştir. Bir başka dikkati çeken husus da yardımların her gelen göçmene yapılmadığ 1 bilgisine ulaşılmıştır. Kimin neye ihtiyacı varsa o nispette ihtiyacının karşılanması bunların dışında kalanlara ise yardım yapılmaması yönünde karar verilmiştir. Gelen muhacirlere yardımlar ve arazi tahsislerinin devletin gelirlerinde önemli kayıplara sebep olduğu anlaşılmaktadır. Örneğin Aydın'da bulunan miri arazilerin muhacirlere tahsis edilmesi sebebiyle devletin bu arazilerden 2565 bin elli dokuz kuruş kaybının olduğu bildirilmiştir. Bu kaybın nasıl telafi edileceği hususu maliye hazinesine sorulmaktadır. ${ }^{9}$

Kafkaslar ve Balkan dağlarının soğuk ikliminden gelen göçmenler Anadolu'nun kıyı bölgelerine özellikle de sahillere yerleştirilince sıcaktan zarar görmüşlerdir. Antalya'ya gelen muhacirlerde bu durum açık olarak görülmektedir. Yerleştikleri bölgenin sıcak olması sebebiyle serin dağlık yerlerden gelen göçmenler iklime uyum sağlayamamışlar hava değişimi sebebiyle hasta olmuşlardır. Şartların uygun olmaması ve sıcak iklime alışamadıkları gerekçesiyle kendilerine komisyon tarafından önerilen yerleşim birimlerinde ikamet etmemişler,yaşayacakları iklimle uyumlu bir mahal gösterilmediği takdirde Antalya mutasarrıflığına şikâyet edeceklerini bildirmişlerdir. Nitekim böyle bir şikâyette vukuu bulmuş "Sahillere ve sıcak bölgelere yerleşmek istemiyoruz." şeklinde dilekçe vermişlerdir. ${ }^{10}$ Muhacirler, alışa geldikleri hayat şartlarına uygun dağ eteklerinde ve yüksek yerlerde yaşayabilecekleriuygun alanların serin ve yüksek yerler olduğunu dile getirerek oralarda iskân edilmek istediklerini bildirmişlerdir.

Akdeniz sahillerine Balkanlar, Girit hatta Kafkasya üzerinden gemilerle deniz yoluyla muhacir sevkiyatı yapılmıştır. Kafkas muhacirlerinin başlangıçta İstanbul merkeze getirilerek nerelere gönderilecekleri, hangi güzergâhı kullanacakları tespit edilmekteydi. Ancak daha sonra en kısa yoldan en kısa sürede iskân edilecekleri bölgelere gönderilmesi kararlaştırılmıştır. Balkanlardan deniz yoluyla gelen göçmenlerden bir kısmı Akdeniz sahil şehirlerine yönlendirilmişlerdir. Bu güzergâhlardan

\footnotetext{
${ }^{8}$ MV., 62-86, H. 13.07. 1308/ 22 Şubat 1891.

9 i...MMS. 60-2859, H. 08.03.1296/ 22 Şubat 1879.

10 I..DH.., 1226-95953, H. 23. 9 1309/ 21 Nisan 1892.
} 
birisi de Çanakkale limanı olmuştur. Çanakkale üzerinden gelen muhacirlerin bindirildiği gemiler Lapseki limanını da kullanarak güneye taşınmışlardır. Güneye göçe tabi tutulanların hangi şehirlere gittiği konusunda elimizdeki bir belgede bazı sayılaraulaşılmıştır. Antalya, Mersin, Beyrut ve İskenderun limanına 1295/ 1878 tarihli bir kayda göre İngiliz vapuruyla Bosna'dan 2263, Selanik'e 622 ve Murat Nusret adlı bir vapurla İzmir'e 5041 ve yine İzmir'e 6923 göçmenin geldiği kaydedilmiştir. Bu kafileyle Anadolu'nun güney sahillerine ve diğer Akdeniz şehirlerine gönderilen muhacir 11.060 olarak yazılmıştır. Belgenin devamında ise Avusturya'nın Luyid şirketinden kiralanacak bir gemiyle 2455 muhacirin getirilmesi için aynı şirketle anlaşmaya varılmıştır. ${ }^{11}$ Anadolu'ya yapılan bu göçler şehirlerde belirli gurupların sayıca artmalarına sebep olmuştur. Dolayısıyla bulundukları mahallerde şehrin yönetiminde de zaman zaman söz sahibi olmaya çalışmışlardır. Örneğin Adapazarı'nda Kafkas muhacirlerinden Çerkes Mahmut Ağa, Adapazarı İdare Meclisi azalığı için seçime katılmış fakat kazanamamıştır. ${ }^{12}$

Balkanlar'dan yine deniz yoluyla göçmen sevkiyatı yapılmıştır. Bulgaristan'da Müslüman ve Türklerin göç ettirilesi devam etmiştir. Göçmenlerin Varna iskelesi yoluyla Hüdavendigar vilayetine atmış sekizgöçmenin gönderildiği belgelerde yer almaktadır. ${ }^{13} \mathrm{Bu}$ belgeye konu olan nüfus miktarının azlığı göç dalgasının 93 Harbi sonrasında yavaşladığının bir işareti olarak sayılabilir.

\section{Sonuç}

Tarihin akışı içinde göç Türkün kaderi olmuştur. Türk milleti, anavatan Türkistan'dan dünyanın her tarafına yayılmıştır. Gittiği yerlere medeniyetini götürmüş, devlet kurmuş ve etrafına da bu medeniyeti taşımıştır. Türk göçleri fetihleri takip ettiği gibi zorunluluklar sebebiyle de olmuştur. Kuraklık, açlık, düşman istilası, korunma ve benzeri gibi pek çok şey göçe sebep olmuştur. Türklerin Anadolu'ya yerleşmeleri de göçlerle olmuştur.

Fakat incelenen dönemde Osmanlı Devleti'nin fetihlerle beraber yayıldığı geniş coğrafyadan Anadolu'ya dönmesiyle göçler de

\footnotetext{
11 Y..PRK. KOM., 1-54, H. 15. 121295 / 10 Aralık 1878, lef 1-23.

12 DH. MTV. , 40/22, H. 09.05.1329/8 Mayıs 1911.

13 Y..PRK.., KOM., 4-71, H. 27.11. 1302/ 7 Eylül 1885.
} 
başlamıştır. Özellikle göçler Kafkaslardan ve Balkanlardan gerçekleşmiştir. Gelen göçmenler yenilen ve çekilen orduların önünden kaçarak gelmişlerdir. Bundan dolayı muhacirler büyük zorluklar yaşamışlardır. Kafkaslarda Rus yayılmasından kaçan bölgedeki Müslüman ve Türk halkı Anadolu'ya sığınmıştır. Benzer şekilde Balkanlardan da Rus ordularından ve Bulgarlardan kaça bilenler Anadolu'ya gelmiştir.

1877-1878 yıllarında yaşanan Osmanlı Rus harbi Balkanlardan Anadolu'ya yoğun göçlerin başlangıcı olmuştur. Özellikle Balkanlarda Bulgarların Türk ve diğer Müslüman unsurları yurtlarından göçe zorlayarak Bulgar nüfusunun çoğunluk olduğu bir yurt meydana getirmek istiyorlardı. Bu sebepten dolayı Türk ve Müslüman halk hem savaşlarda hem de Bulgar çetelerinden dolayı katliama uğramıştır. Kaça bilenler yollarda da telefata uğrayarak canlarını kurtarmaya çalışmışlardır. Dolayısıyla burada sistematik bir hareketle soykırım yapılmış, kaçabilenler Anadolu'ya sığınmıştır.

$\mathrm{Bu}$ şartlar altında Anadolu, yaklaşık yüz yıldır yoğun bir muhacir baskısına uğramıştı. Kırım'ın kaybından itibaren halen bu göç dalgası devam etmektedir. İstanbul hükümeti dört bir yandan gelen muhacirleri Anadolu'nun değişik şehirlerine geldikleri şehirlerin özelliklerine uygun yerlere yerleştirmeye çalışmıştır. Gelenlerin ihtiyaçlarını karşılandığı gibi işleyip geçimlerini sağlayacakları toprak ve tohumluk vermiştir. Ev yapımı için kereste bedelsiz karşılanmıştır. Anadolu halkı da elinden geldiği kadarıyla muhacirlere destek olmuştur. 


\title{
EXTENDED ABSTRACT
}

\section{Immigrances of Anatolia in The Last Term of The Ottoman State and Public Policies in Countries of Immigrants}

\author{
Ahmet Oğuz \\ Nevşehir Hacı Bektaş Veli University
}

The Otoman Empire entered a reconstruction period after winning the Crimean War together with its allies. But sings of disintegration began after the 93 War. After this date, migrations to Anatolia intensified. Russia's occupation of the Ottoman's Balkans and Caucasus territories where the Muslim-Turkish population was concentrated had caused mass migration wave flowed to Anatolia. In addition to the harsh conditions of the war, a wave of immigration had been added. The second great wave of migration of the Ottoman Empire began with the loss of the Balkan War and continued afterwards.

The Ottoman Empire was crushed under the wave of migration that started with the loss of the 93 War. The state had made great efforts to send the Balkan immigrants gathered in Istanbul to the different parts of the country. The refugees were first gathered in Istanbul and then sent to the appropriate cities. During this migration, the Circassian immigrants problem emerged. At the time the parliament (Meclis-i Mebusan) was open, Circassian immigrants issue had caused controversy among deputies. The Circassians in the immigration wave from the Balkans had created a separate problem. The Circassians, an organized group, started plundering in the regions where they went. Their unlawful actions had caused criticism. Even there had been complaints that the Circassians occasionally harmed the Muslim population.

One of the most important migration events took place in the aftermath of the Balkan Wars of 1911-1912. Because the Muslim population was very dense in the lands which was lost. Therefore, the migration to Anatolia 
was more than the previous ones. Another negative factor was the regression of the state's facilities. Moreover, Anatolian cities were not as eager to receive migration as before.

Despite all the difficult conditions and limited opportunities, refugees from the Balkans and the Caucasus were settled in Anatolia. One of the important issues in the last years of the Ottoman empire was immigration and refugees. All possibilities had been mobilized to ensure their housing, nutrition and to adapt to society.

Migration to Anatolia began with the defeat of the Ottoman Empire in the Balkans. The tragic aspect of migration is that it had collective. The loss of the first Muslim Turkish territory Crimea gave rise to mass migration. The events have led to an increase in nationalist movements in the Balkans. This triggered wars. Therefore, the Balkans started to emigrate from the $19^{\text {th }}$ century. The necessity of migration had increased the degree of difficulty. Because of the avoidance of wars, life anxiety can be added to this difficulty. The Muslim people, who could escape from the enemy soldiers, suffered great losses on the roads. The Balkan lands of the Ottoman Empire were therefore subjected to a continuous wave of migration. Muslim people who immigrated until the 1877-1878 Ottoman Russian War (called the 93 War) settled in other cities close to Istanbul. But after the 93 war, there were migrations to Istanbul from almost all over the Balkans.

In Istanbul, the situation turned into disaster after the 93 War. The capacity of the capital could not bear the immigrants from all over the Balkans. Nutrition and housing problems had arisen in Istanbul. All places that can be accommodated in the city had filled with immigrants. Even Sultan Abdulhamit II hosted a group of immigrants in the palace. Immigrants who living in poverty and misery perished with epidemics. The Ottoman rulers directed migration to Anatolia through the immigration commission. Migrants were directed to the appropriate cities of Anatolia. Anatolian cities that allowed immigrants for many years, rejected some cities requests to send refugees.

There had been migrations from the Caucasus to Anatolia. As the Russian attacks increased, so did the migrations. After the Turkmenchay agreement, the Armenian population increased in the region. The Muslim population in the Erivan and its environment turned to Anatolia with the 
Russians bringing Armenian population. Therefore, Anatolia had been subjected to migration pressure from both sides. Migrants, who originally came from the Caucasus, were directed to Istanbul. However, the immigration density increased so much that this application was abandoned. Who came from the Caucasus were also directed directly to the Anatolian cities.

Emigrants in Anatolian cities were generally well received. However, due to the climate and natural conditions of these regions the problems arose in the migrants. Immigrants from mountainous and cool places did not want to settle on the shores. Who settled on the coasts were transferred to the appropriate places with the decision of the immigration commissions established in the provinces. The Anatolian people have provided the necessary financial and moral assistance to these poor people. They provided seed for agricultural activities and assisted in the construction of houses.

State support was also provided to immigrants. Wood was given to the builders. Soil is provided for agriculture. These people were exempted from taxation in certain time. Although the state lost income due to this situation, the state support was provided to the immigrants even under difficult conditions. The Mediterranean Sea, Konya, Aydın and Bursa were the most common areas of migration. The immigrants especially were settled in Cukurova and its enviros, Bursa, Eskisehir, Yozgat, Kastamonu, Izmir and many other Anatolian cities.

\section{Kaynakça / References}

Çetin, A.- ve Galip Ç.(2013). Arşiv belgelerine göre Kosova'nın İslamlaşmasına dair Osmanlı uygulamaları. (Editörler: İskefiyeli, Z., Çelik, B. ve Yazıcı, S.) Türk Tarihinde Balkanlar içinde Sakarya: Sakarya Üniversitesi Yayınları.

Demirel, M. (2009). Artvin ve Batum göçmenleri(1877-1878 Osmanl1-Rus savaşı'ndan sonra. Türkiyat Araştırmaları Dergisi, 40, 317-340.

Gayretullah, H. (2006). ‘Bir göç hikâyesi: Doğu Türkistan'dan göç hatıraları. Uluslararası Göç Sempozyumu, 8-11 Aralık 2005 İstanbul.

İpek, N. (1999). Rumeli'den Anadolu'ya Türk göçleri. Ankara: TTK Yayınları. 
Kaflı, K. (1966). Türkiye'ye göçler. İstanbul: Çeltük Matbaacıllk.

Karal, E. Z. (1988). Osmanl tarihi birinci meşrutiyet ve istibdat devirleri (18761907), cilt VIII, Ankara: TTK Yayınları.

Karpat, H. K. (2013). Osmanlıdan günümüze etnik yapılanma ve göçler. 2. Baskı. İstanbul: Timaş Yayınları.

Karpat, H. K.(2004). Balkanlar'da Osmanlı mirası ve ulusçuluk, çev: Recep Boztemur. İstanbul: İmge Kitabevi.

MCcarthy, J. (1995). Ölüm ve sürgün. İstanbul: İnkılap Yayınları.

Oğuz, A. (2010). Birinci Meşrutiyet Kanun-ı Esasi ve Meclis-i Mebusan. Ankara: Grafiker Yayınları.

Paşaoğlu, D. (2013). Muhacir komisyonu maruzatı'na göre (1877-78) 93 harbi sonrası muhacir iskânı. History Studies, 5(2), 347-387.

Saraç, H. (2011). Osmanlı' dan cumhuriyet'e köy-mezra, köy-yayla arasındaki göçlerin şehir hayatına etkisiyle meydana gelen değişikliklerin kültürel hayattaki yansımaları: Atdeşen(Rize) Yaylaları Örneği 1880-2010, CIEPO, Ulaslar Arası Osmanlı Öncesi ve Osmanlı Tarihi Araştırmaları 6. Ara Dönem Sempozyum Bildirileri, 14-16 Nisan 2011, Uşak: 1051-1065.

Uzunçarşılı, İ. H. (2007). Osmanlı tarihi Karlofça anlaşmasından XVIII. yüzyılın sonlarına kadar, cilt IV I. bölüm, Ankara: TTK Yayınları, 6. Baskı.

Yetişgin, M. (2013). On dokuzuncu asrın son çeyreğinde Rusların balkan politikası. (Editörler: İskefiyeli, Z., Çelik, B. ve Yazıcı, S.) Türk Tarihinde Balkanlar içinde Sakarya: Sakarya Üniversitesi Yayınları.

\section{Başbakanlık Osmanlı Arşiv Belgeleri}

B.O.A, DH. MKT.( Dahiliye NezâretiMektubî Kalemi), 1393-72, H. 24.4.1304 /20 Ocak 1877.

B.O.A, DH.. İ. D.(Dahiliye İdari Kısım), 85-1, H. 13. 9. 1328/ 18 Eylül 1910.

B.O.A, BEO. (Bâb-1 Âlî Evrak Odası), 107-8004, H. 26.04. 1310/ 17 Kasım 1892.

B.O.A, DH.. İD. (Dahiliye İdari Kısım), 60-15, H. 22.9.1330/ 4 Eylül 1912.

B.O.A, MV.( Meclis-i Vükelâ Mazbataları), 62-86, H. 13.07. 1308/ 22 Şubat 1891.

B.O.A, İ..MMS.( İrâde - Meclis-i Mahsus), 60-2859, H. 08.03.1296/ 22 Şubat 1879.

B.O.A, İ..DH..( İrâde - Dahiliye), 1226-95953, H. 23.9 1309/ 21 Nisan 1892. 
B.O.A, Y..PRK. KOM.( Yıldız Perakende Evrakı Sadâret, Umum Vilayetler Tahrirâtı), 1-54, B.O.A, H. 15.121295 / 10 Aralık 1878, lef 1-23.

B.O.A, DH. MTV.(Mütenevvia Kısmı Belgeleri), 40/22, H. 09.05.1329/ 8 Mayıs 1911.

B.O.A, Y..PRK.., KOM.( Yıldız Perakende Evrakı Sadâret, Umum Vilayetler Tahrirâtı), 4-71, B.O.A, H. 27.11. 1302/ 7 Eylül 1885.

B.O.A, DH. MKT.( Dahiliye NezâretiMektubî Kalemi), 1346/25, H. 16. 2. 1302 / 5 Aralık 1884.

B.O.A, Y..PRK.., KOM.(Yıldız Perakende Evrakı Sadâret, Umum Vilayetler Tahrirâtı), 4-71, B.O.A, H. 27.11. 1302/ 7 Eylül 1885.

\section{Kaynakça Bilgisi / Citation Information}

Oğuz, A. (2019). Osmanlı devletinin son döneminde anadolu'ya gelen muhacirler ve muhacirlerin göç ettiği bazı şehirlerdeki iskân politikaları. OPUS-Uluslararası Toplum Araştırmaları Dergisi, 13(19), 2709-2728. DOI: 10.26466/opus.576880 